\title{
Front Matter: Volume 9222
}

"Front Matter: Volume 9222," Proc. SPIE 9222, Imaging Spectrometry XIX, 922201 (30 September 2014); doi: 10.1117/12.2086631

SPIE Event: SPIE Optical Engineering + Applications, 2014, San Diego, California, SPIE. United States 


\section{PROCEEDINGS OF SPIE}

\section{Imaging Spectrometry XIX}

Pantazis Mouroulis

Thomas S. Pagano

Editors

18 August 2014

San Diego, California, United States

Sponsored and Published by

SPIE

Volume 9222

Proceedings of SPIE 0277-786X, V. 9222

SPIE is an international society advancing an interdisciplinary approach to the science and application of light.

Imaging Spectrometry XIX, edited by Pantazis Mouroulis, Thomas S. Pagano, Proc. of SPIE Vol. 9222, 922201

(C) 2014 SPIE · CCC code: 0277-786X/14/\$18 doi: 10.1117/12.2086631 
The papers included in this volume were part of the technical conference cited on the cover and title page. Papers were selected and subject to review by the editors and conference program committee. Some conference presentations may not be available for publication. The papers published in these proceedings reflect the work and thoughts of the authors and are published herein as submitted. The publisher is not responsible for the validity of the information or for any outcomes resulting from reliance thereon.

Please use the following format to cite material from this book:

Author(s), "Title of Paper," in Imaging Spectrometry XIX, edited by Pantazis Mouroulis, Thomas S. Pagano, Proceedings of SPIE Vol. 9222 (SPIE, Bellingham, WA, 2014) Article CID Number.

ISSN: 0277-786X

ISBN: 9781628412499

Published by

SPIE

P.O. Box 10, Bellingham, Washington 98227-0010 USA

Telephone +1 3606763290 (Pacific Time) · Fax +1 3606471445

SPIE.org

Copyright (C) 2014, Society of Photo-Optical Instrumentation Engineers.

Copying of material in this book for internal or personal use, or for the internal or personal use of specific clients, beyond the fair use provisions granted by the U.S. Copyright Law is authorized by SPIE subject to payment of copying fees. The Transactional Reporting Service base fee for this volume is $\$ 18.00$ per article (or portion thereof), which should be paid directly to the Copyright Clearance Center (CCC), 222 Rosewood Drive, Danvers, MA 01923. Payment may also be made electronically through $\mathrm{CCC}$ Online at copyright.com. Other copying for republication, resale, advertising or promotion, or any form of systematic or multiple reproduction of any material in this book is prohibited except with permission in writing from the publisher. The CCC fee code is 0277-786X/14/\$18.00.

Printed in the United States of America.

Publication of record for individual papers is online in the SPIE Digital Library.

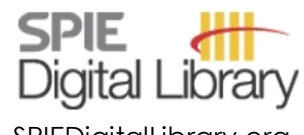

SPIEDigitalLibrary.org

Paper Numbering: Proceedings of SPIE follow an e-First publication model, with papers published first online and then in print and on CD-ROM. Papers are published as they are submitted and meet publication criteria. A unique, consistent, permanent citation identifier (CID) number is assigned to each article at the time of the first publication. Utilization of CIDs allows articles to be fully citable as soon as they are published online, and connects the same identifier to all online, print, and electronic versions of the publication. SPIE uses a six-digit CID article numbering system in which:

- The first four digits correspond to the SPIE volume number.

- The last two digits indicate publication order within the volume using a Base 36 numbering

system employing both numerals and letters. These two-number sets start with 00, 01, 02, 03, 04,

$05,06,07,08,09,0 A, 0 B \ldots$. OZ, followed by 10-1Z, 20-2Z, etc.

The CID Number appears on each page of the manuscript. The complete citation is used on the first page, and an abbreviated version on subsequent pages. Numbers in the index correspond to the last two digits of the six-digit CID Number. 


\title{
Contents
}

\author{
$\checkmark$ Authors \\ vii Conference Committee
}

\section{SESSION 1 SENSOR SYSTEMS AND APPLICATIONS}

922202 Observing system simulation experiments to assess the potential impact of proposed satellite instruments on hurricane prediction [9222-1]

922203 Simulating satellite infrared sounding retrievals in support of Observing System Simulation Experiments (OSSEs) [9222-2]

922206 Differentiation of bacterial colonies and temporal growth patterns using hyperspectral imaging [9222-5]

922207 Modeling the expected performance of the REgolith X-ray Imaging Spectrometer (REXIS) [9222-6]

\section{SESSION 2 NEW SENSORS AND MISSIONS}

922208 Characterization and performance of the Prototype HyspIRI-TIR (PHyTIR) Sensor [9222-7]

922209 Multislit optimized spectrometer: flight-like environment test results [9222-8]

\section{SESSION $3 \quad$ IMAGING SPECTROMETER DEVELOPMENT AT JPL}

9222 OB Lessons and key results from 30 years of imaging spectroscopy (Invited Paper) [9222-10]

9222 0C Design of the Compact Wide Swath Imaging Spectrometer (CWIS) [9222-11]

9222 OD Optical design of a CubeSat-compatible imaging spectrometer [9222-12]

9222 OE Wide-field imaging spectrometer for the Hyperspectral Infrared Imager (HyspIRI) mission [9222-13] 
9222 OG Radiometric sensitivity contrast metrics for hyperspectral remote sensors [9222-15]

$9222 \mathrm{OH}$ Modeling effects of the bidirectional reflectance distribution function on remote sensing in the LWIR [9222-16]

$92220 \mathrm{~J}$ Using kernel-based and single-scattering albedo approaches for generalized spectral mixture analysis of hyperspectral imagery [9222-18]

9222 OK Spatial-spectral metric learning for hyperspectral remote sensing image classification [9222-19]

\section{POSTER SESSION}

$92220 \mathrm{M}$ lonospheric imaging using merged ultraviolet airglow and radio occultation data [9222-21] 


\section{Authors}

Numbers in the index correspond to the last two digits of the six-digit citation identifier (CID) article numbering system used in Proceedings of SPIE. The first four digits reflect the volume number. Base 36 numbering is employed for the last two digits and indicates the order of articles within the volume. Numbers start with 00, 01, 02, 03, 04, 05, 06, 07, 08, 09, 0A, 0B...0Z, followed by 10-1Z, 20-2Z, etc.

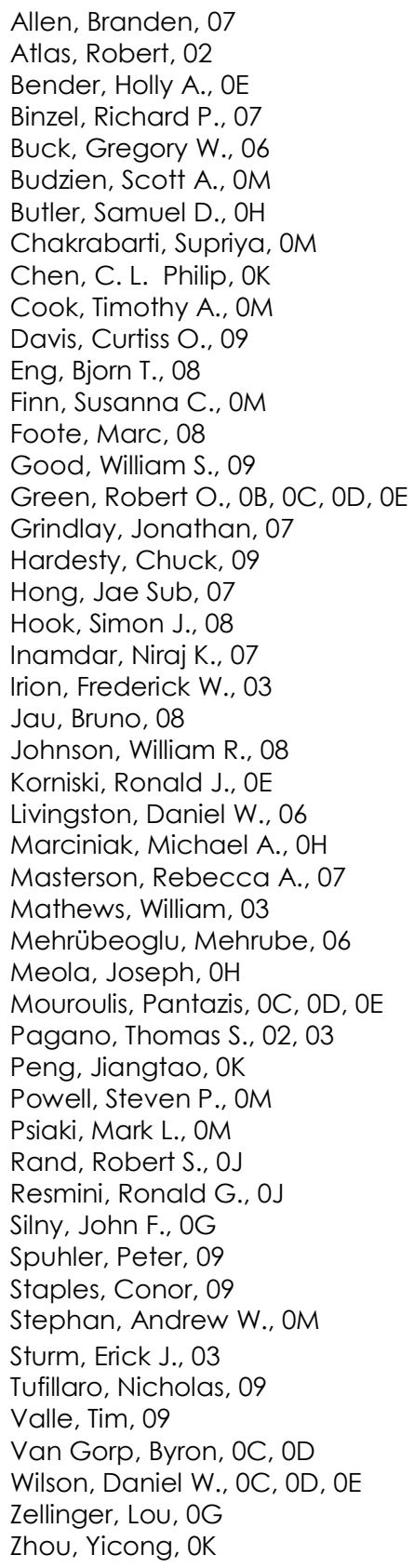


Proc. of SPIE Vol. $9222922201-6$

Downloaded From: https://www.spiedigitallibrary.org/conference-proceedings-of-spie on 25 Apr 2023 Terms of Use: https://www.spiedigitallibrary.org/terms-of-use 


\title{
Conference Committee
}

\author{
Program Track Chair
}

Allen H.-L. Huang, University of Wisconsin-Madison (United States)

Conference Chairs

Pantazis Mouroulis, Jet Propulsion Laboratory (United States)

Thomas S. Pagano, Jet Propulsion Laboratory (United States)

Conference Program Committee

Christoph C. Borel, Air Force Institute of Technology (United States)

Chein-I Chang, University of Maryland, Baltimore County

(United States)

François Châteauneuf, INO (Canada)

Thomas Cooley, Air Force Research Laboratory (United States)

Eustace L. Dereniak, College of Optical Sciences, The University of Arizona (United States)

Bo-Cai Gao, U.S. Naval Research Laboratory (United States)

Robert O. Green, Jet Propulsion Laboratory (United States)

Kevin C. Gross, Air Force Institute of Technology (United States)

Emmett J. lentilucci, Rochester Institute of Technology (United States)

Robert T. Kroutil, Dynamac Corporation (United States)

Mehrube Mehrubeoglu, Texas A\&M University Corpus Christi (United States)

Joseph Meola, Air Force Research Laboratory (United States)

Jose F. Moreno, Universitat de València (Spain)

Luc Rochette, LR Tech (Canada)

Michael E. Schaepman-Strub, Zurich University of Applied Sciences

(Switzerland)

John F. Silny, Raytheon Space \& Airborne Systems (United States)

\section{Session Chairs}

1 Sensor Systems and Applications

Pantazis Mouroulis, Jet Propulsion Laboratory (United States)

2 New Sensors and Missions

Thomas S. Pagano, Jet Propulsion Laboratory (United States)

3 Imaging Spectrometer Development at JPL

Steven A. Macenka, Jet Propulsion Laboratory (United States)

4 Modeling, Phenomenology, and Algorithms

Thomas S. Pagano, Jet Propulsion Laboratory (United States) 
Proc. of SPIE Vol. $9222922201-8$

Downloaded From: https://www.spiedigitallibrary.org/conference-proceedings-of-spie on 25 Apr 2023 Terms of Use: https://www.spiedigitallibrary.org/terms-of-use 